\title{
Theology \\ and \\ Philosophy of Religion
}

\section{INTRODUCTION}

Trends and movements are mercurial things, difficult to identify over any significant period of time. In the areas of both Christian Doctrine and Philosophy of Religion, there is a multiplication of volumes which by its very massiveness creates a problem for the purchaser of books for a ministerial library. What is needed, in many cases at least, is a guide to selectivity. This in turn is made more difficult in the case of recent publications by the fact that the disciplines are subject to what may be called a "Guru mentality" which seeks for some one prominent teacher, and then adopts him as a personal mentor.

This "Guru mentality" expresses itself most prominently in our time in one of two directions. Either the leadership of Paul Tillich is accepted, usually without too much critical analysis in advance, and then certain catch-phrases of the famous theologian become determinative for theological discussion, or else the methodology of Rudolf Bultmann is seized as offering a way out of modern man's theological illiteracy, and theological discussion is tailored to fit. Some are, however, beginning to question whether either of these men is of sufficient permanent significance to warrant adoption as one to be followed, whithersoever he may go.

Thus, there has been, within a decade, somewhat of a shift from the faddism of a movement, to a faddism of men. Ten years ago, Existentialism was a fad to the extent that many thinkers believed that he who failed to read at least something from Soren Kierkegaard or Nartin Heidegger was a theological boor. The one-sidedness of Existentialism as a movement led many to turn from it as a guiding-star in their thought, as men turn from all parochialisms, given time. One is tempted to wonder how long either Paul Tillieh or Rudolf Bultmann will be

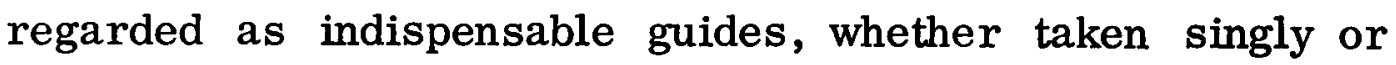


together, to fruitful discussion in the disciplines of Theology or of Philosophy of Religion.

\section{Christian Theology}

Baker's Dictionary of Theology, ed. by E. F. Harrison, G. W. Bromiley, and Carl F. H..Henry. Grand Rapids: Baker, 1960. $\$ 8.95$.

This excellent resource book provides the reader with a positive exposition of the biblical content in each topic, and at the same time seeks to indicate the tension points in theological discussion. It is the most complete and comprehensive work of its kind to appear for several decades.

\section{Systematic Theology}

Christian Theology, by H. Orton Wiley. Kansas City: Beacon Hill Press, 1940, 1943. 3 Vols. $\$ 3.95$ each volume.

The late $\mathrm{H}$. Orton Wiley has presented in these volumes the most thorough and comprehensive work on Christian theology in the Wesleyan-Arminian tradition since the beginning of the present century. The material is organized into six divisions, each consisting of several chapters. The first division is devoted to "The Province of Theology, "while successive divisions, or parts, present the doctrines of the Father, the Son, the Holy Spirit, the Church, and Last Things.

The work is scholarly, evangelical, and biblical. There is frequent documentation, and in addition to the author's own composition there are many references in the form of footnotes from a large number of standard theological works. Volume III contains a general bibliograly pages, and a general index for the three volumes.

Church Dogmatics, by Karl Barth. New York: Scribner's,1936-

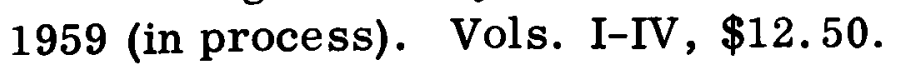


Barth's Dogmatics is the most prodigous theological production of the contemporary religious world. There are eleven volumes thus far, seven of which have been translated into English. It expresses the position of "Dialectical Theology," commonly termed "Neo-orthodoxy." However one may feel toward Karl Barth and his system, he should understand what the Swiss theologian is saying. This series is indispensable to such an understanding.

For some years, writers have differed in their evaluations of Karl Barth's work. Some insisted that we must distinguish between the "older Barth" and the "newer Barth" while others can see no othe $r$ than "tne same old Karl Barth." A case can be made for the view that some philosophical features underlie all of Barth's thinking; but in the particulars of Christian doctrines, it is clear from his Church Dogmatics that he has moved, in many phases of his thought, toward a "theology of Grace" which has much in common with historic Christianity. For a criticism of the Church Dogmatics which is, on the whole, constructive, the reader is referred to G. C. Berkouwer's volume, The Triumph of Grace in the Theology of Karl Barth (Grand Rapids: Eerdmans, 1956 edition in paperback, \$2.45).

Institutes of the Christian Religion, by John Calvin. Trans. by John Allen. 7th American ed. Philadelphia: Presbyterian Board of Christian Education, 1936. 2 vols. (Westminster Press, \$12.00)

Calvin's work is one of the greatest systematic theological treatments of all time; a classic in the history of Christian thought. It represents the Reformed tradition of the Reformation as over against the Lutheran and Arminian types.

Systematic Theology, by Paul Tillich. Chicago: University of Chicago Press, 1951, 1957. 2 vols. Vol. I, \$5.50; Vol. II, $\$ 4.50$.

In many ways Tillich's workis unique, in which, by a "method of correlation, "faith or revelation seeks to answer the questions of philosophy. Two volumes have appeared thus far, with a third yet to come. It is this thixd volume which should be crucial for a statement of the applicability of the Christian message to human Iife $_{\text {e USED WITHOUT COPYRICHT PERMISION }}$ 
While Professor Tillich has written a great deal in the past, it is in this work that he sets forth his theological system. The first two volumes seem to suggest that his theology contains strongly gnostic elements, and that he is little concerned with the content of the Bible as a source for theology, unless that content be subjected to an "existential" type of interpretation which seems to leave it something far different from an authoritative revelation. Volume III should give to the theological reading public Tillich's view of applied redemption. It is not easy to foresee what his kerygma will be at this point.

\section{Doctrinal Theology}

Basic Christian Doctrines, by Carl F. H. Henry, Ed. New York: Holt, Rinehart and Winston, 1962. \$6.00.

An interdenominational and international corps of evangelical writers present in this volume a series of concise essays on forty-three doctrines of the Christian faith. The series first appeared fortnightly in Christianity Today over a two-year period, and is now made available in permanent form for both clergymen and laymen. Publication of these essays in a very attractive format is the third volume in a series on "Contemporary Evangelical Thought." Companion symposium volumes are Contemporary Evangelical Thought (1957) and Revelation and the Bible (1958).

As might be expected, there are occasions when varied denominational traditions are evident in some areas, while the greater common denominator throughout is fidelity to biblical authority as the norm for the Christian faith. The essayists have defined and expounded the various doctrines, as well as noting contemporary theological emphases and trends which are relevant. There is a selected bibliography at the conclusion of each essay, thus suggesting sources for those who desire to explore the area of study more thoroughly. swo of the contributors in this volume are on the staff of Asbury Theological Seminary.

Christianity and Liberalism, by J. Gresham Machen. Grand Rapids: Eerdmans, 
This volume is a polemic for supernatural, historic, biblical Christianity with a searching analysis of Liberalism and its weaknesses. With incisive clarity Dr. Machen discusses the following subjects: Doctrine, God and Man, The Bible, Christ, Salvation, and The Church. The relevancy of his work continues in this "post-liberal" era.

The Death of Christ, by James Denney. 2nd ed. Philadelphia: Westminster Press, 1903. Revised edition, by R. V. G. Tasker, Ed. London: The Tyndale Press, 1951. (Intervarsity Press, \$3.95.)

A careful examination of the New Testament teaching on the atonement is the burden of this book. The death of Christ, in Denney's view, provides not only the essential clue to a proper understanding of the person and work of Christ, but is the proper basis for the unity of both the Old and New Testaments. Many consider this book to be the outstanding discussion of the subject. There have been five reprintings since the revised edition first appeared in 1951. It is a tribute to the abiding value of Denney's work.

Exploring Our Christian Faith, ed. by W. T. Purkiser. Kansas City: Beacon Hill Press, 1960. \$5.50.

Eight scholars of the Nazarene Church have collaborated to present in a single volume of twenty-eight chapters an admirable treatment of the Christian faith. Each chapter, which discusses a major phase of Christian doctrine, is written with an awareness of contemporary issues on the subject, and at the same time provides a positive exposition of the biblical content. Sources for additional reading are cited under each topic. The three chapters on sanctification are exceedingly well done. This is the most thorough and helpful volume on the doctrines of the Christian faith in the Wesleyan-Arminian heritage in recent years.

Major Voices in American Theology and Men Who Shape Belief, by David Wesley Soper. Philadelphia: The Westminster Press, 1953,1955 . \$3.50, to BE USED WITHOUT COPYRIGHT PERMISSION 
These volumes give an appreciative interpretation and appraisal of the lives and writings of seventeen leading American theologians. The first volume includes Edwin Lewis, Reinhold Niebuhr, Nels F. S. Ferre, Paul Tillich, H. Richard Neibuhr, and Robert L. Calhoun.

Included in the second volume are analyses of James Luther Adams, Douglas V. Steere, John A. Mackay, Walter M. Horton, John C. Bennett, Wilhelm Pauck, Harris Franklin Rall, W. Norman Pittenger, Louis Berkhof, Henry N. Wieman, and Edgar S. Brightman.

The Nature and Destiny of Man, by Reinhold Niebuhr. New York: Scribner's, 1941-43. 2 vols. 2 vols. in one, $\$ 5.95$.

These Gifford Lectures are the most systematic presentation of Niebuhr's thought and at the same time the most influential of his writings. From the neo-orthodox point of view, a penetrating analysis of human nature is presented in volume one, in which the author shows the inadequacies of non-Christian interpretations of man as over against the Christian view. Volume two discusses human destiny and the Christian doctrine of salvation.

Philosophical Theology, by F. R. Tennant. Cambridge: Cambridge University Press, 1928-1930. 2 vols. Vol. I, $\$ 8.50 ;$ Vol. II, $\$ 5.50$.

It is the stated purpose of this study to present a critical discussion of "those tracts of philosophy which have bearing on the cognitive basis of religion." Beginning with a vigorous and acute examination of the facts and principles of psychology, and continuing with the processes of humandealings with the world, the author seeks to show the reasonableness of a theistic view. Volume one is entitled The Soul and Its Faculties; volume two, The World, The Soul, and God.

Rejecting simple rationalism, Professor Tennant seeks to establish a form of empicical apologetic, based on his view of the validity of three approaches psychological empiricism, empirical rationalism, and empixical metaphysics. On these grounds he established, firmly he feels, belief in the existence of God and of the him 
A Right Conception of Sin, by Richard S. Taylor. Kansas City: Beacon Hill Press, 1945 (revised).

This small volume sets forth in a clear, concise manner a helpful discussion on an important subject. The WesleyanArminian interpretation is emphasized as it may differ from the Calvinistic point of view.

Types of Modern Theology, by H. R. Mackintosh. New York: Scribner, 1939. \$4.00.

A brilliant analysis of the theologies of Schleiermacher, Hegel, Ritschel, Troeltsch, Kierkegaard, and Barth, is presented in this volume. It is an excellent survey on modern trends in Christian thought.

\section{Inspiration and Revelation}

In spiration and Interpretation, by John W. Walvoord, Ed. Grand Rapids: Wm. B. Eerdmans Publishing Co., 1957. \$4.50.

Ten scholars, mostly from leading evangelical seminaries of America, participated in producing this symposium under the auspices of the Evangelical Theological Society. The first five chapters demonstrate that belief in the full inspiration, inerrancy, and authority of the Scripture was supported by such giants as Irenaeus, Augustine, Luther, Calvin, and Wesley. Of particular value to Wesleyan Arminians is Dr. Turner's chapter on "John Wesley as an Interpreter of Scripture." The next four chapters trace the failure of recent attempts to effect a reconcillation between liberal trends of biblical criticism and the inherent values of a "full Christianity." Dr. Henry closes with a masterful defense of the utter trustworthiness of the Scripture.

Revelation and the Bible by Carld F. H. Henry, Ed. Grand Rapids: Baker Book House 1958 \$6.00.

Twenty-five leading evangelical scholars from this country and abroad participated in $_{\mathrm{S}}$ this symposiumm on the authority of 
the Scripture. After a World Evangelical Fellowship conference in Clarens, Switzerland, a discussion of contemporary Protestant theology had issued in a realization of the importance of a volume that would give united expression to the evangelical position as a solid base for faith and life. Chapters include definitive articles on special revelation, biblical evidences for inspiration and canonicity, matters of history, archaeology and criticism, the work of the Holy Spirit, and the trend of Christian thought. A valuable bibliography appears at the end.

Special Revelation and the Word of God, by Bernard Ramm. Grand Rapids: Wm. B. Eerdmans Publishing Co., 1961. \$3.00.

Dr. Ramm does real service by defining in specific terms the issues of special revelation as fundamental to Scripture. Having made the basic concept clear, he then sets forth the four modalities under which God reveals Himself: divine condescension, divine speaking, the historical event, and incarnation. Finally, the products are treated in terms of language and Scripture. Though the book uses many technical terms and introduces rather advanced theological and philosophical concepts, the fundamental ideas are clear and within the reach of the less experienced reader.

\section{Christian Holiness}

Explanatory Notes Upon the New Testament, by John Wesley. London: The Epworth Press, 1950. (A. R. Allenson, \$3.75.)

This work was first published in 1755 , and gives us Wesley's own translation of the New Testament plus his helpful notes (or commentary) upon it. In the Preface, Wesley informs his readers that he wrote the Notes, not for men of learning, but primarily for "plain, unlettered men, who understand only their mother-tongue, and yet reverefice and love the Word of God, and have a desire to save their owa souls." The commentary is chiefly characterized by terse concise notes or comments on the text, and presents theology in concentrated, practical statements. There have been four printings of this valuable publication since $1950^{\circ}$ 
The Holy Spirit, by Jasper A. Huffman. Winona Lake: The Standard Press, 1944.

Professor Huffman, for many years a teacher at Taylor University, presents here a very competent, scholarly, and practical study of the biblical doctrine of the Holy Spirit. It is a timely discussion on a subject which has been neglected in the past, and is frequently abused or much misunderstood in the present. Every chapter is rich in content, and the final chapter on "The Spirit-filled Life" is particularly valuable. A recent large third printing indicates its usefulness and the consistent demand for it.

The More Excellent Way, by George Allen Turner. Winona Lake: Light and Life Press, 1952. \$3.00.

Dr. A. C. Knudsen describes this book as "a work of extraordinary merit." It is indeed a thorough, scholarly study of the Scriptural basis of John Wesley's doctrine of Christian Perfection. Dr. Turner's work is in two parts: Part Idealing with the biblical basis, and Part II with the historical development. Each chapter is carefully summarized.

$\mathrm{Th}$ is volume is unique in that it brings together in a most discerning and penetrating manner the techniques of the inductive method in Bible study and an examination of the biblical basis for the doctrine of Entire Sanctification. The work contains a meticulous survey of what both the Old Testament and New Testament have to say upon the question of Christian sanctity, and in its second half relates the Wesleyan teaching of Christian Perfection to the biblical insights gained by inductive study. Dr. Turner has given to the Christian world a study in this vital area which is without a peer in our century.

The sate Dr. W. E. Sangster of England, a life-long student of Christianholiness, wrote: 1 reredis a piece of serious scholarship on a subject which 600 many people have wiped away in a cavalier fashion and have said, "Warfield finished that off years ago.' Those who think that should read this book--and think again!... The case is stronger than they think." 
A Plain Account of Christian Perfection, by John Wesley. London: The Epworth Press, 1952. (A. R. Allenson, \$2.00.)

This publication is an unabridged edition of Wesley's classical statement of the doctrine of Christian Perfection. This work requires no special recommendation to those who are interested in a clear understanding of this major distinctive of Wesleyan theology.

The Way to Pentecost, by Samuel Chadwick. Berne, Indiana: Light and Hope Publications, 1937. \$1.50.

The dynamic presentation in this volume is not a formal treatise on the Holy Spirit but a selection of articles which appeared from time to time in Joyful News, an English periodical. Each study is deeply spiritual, setting forth Scriptural truth in a pungent, forceful manner.

The author, formerly principal of Cliff College and president of the British Methodist Conference, was one of England's most gifted and effective preachers of the last generation. A final chapter presents "The Way into the Blessing" of a personal Pentecost for the believer.

Wesley's Standard Sermons, ed. by E. H. Sugden. London: The Epworth Press, 1921. 2 Vols. \$5.00.

This is a standard edition of John Wesley's Standard Sermons, including the forty-four sermons which are a doctrinal norm for British Methodism, plus eight additional sermons that Wesley published in an edition of his collected Works in 1771 . There is a helpful introduction to each sermon giving historical and doctrinal data. The many annotations by Sugden are always illuminating, sometimes provocative. Wesley's sermons are characterized by a rich biblical content, and illustrate the manner in which his thorough Iamiliarity with the Scriptures was employed in his preaching ministry.

Wesley's important sermon on 3 The Scripture Way of Salvation" is included in this edition. It is a compact statement of Wesley's mature thought on the great doctrines which inspired the Methodist Revivallg USED WITHOUT COPYRICHT PERMISSION 


\section{Philosophy of Religion}

\section{General Works}

The Dictionary of Philosophy, edited by Dagobert D. Runes, New York: The Philosophical Library, 1942. (Littlefield, paperback ed., \$1.95.)

This volume, although relatively complete in itself, requires some such supplementation as can be offered by the Dictionary of Philosophy and Psychology, edited by James Mark Baldwin (in subjects which the latter discusses). Dr. Runes has brought together an impressive range of writers who treat a wide variety of subjects. Special attention is given to such newer topics as symbolic logic, logical positivism, and the relation of mathematics to philosophy. While many of the entries are short (sometimes tantalizingly so), there are a good number of extended articles. This is a valuable handbook.

Dictionary of Philosophy and Psychology, edited by James Mark Baldwin. 2 vol. New York: Peter Smith, 1940 (new ed.).

This two-volume set is generally regarded as a "standard" research source for the study of all branches of philosophy, including the specialized branch, Philosophy of Religion. It represents the work of a vast range of authors of high competence. The range of topics is massive and inclusive, considering that the major part of the writing occurred in the first decade of this century. There are excellent bibliographies, good illustrations, and helpful indices in a number of languages. For subjects which have come to prominence since 1910, it needs to be supplemented by some such work as the Dictionary of Philosophy, edited by Dagobert D. Runes.

\section{Religious and Christian Philosophy}

The Central Idea of Christianity, by Jesse T. Peck. Louisville: The Herald Press, revised ed. 
Bishop Jesse T. Peck has given to the Christian world a volume which combines in an unusual fashion the penetration which belongs to philosophical endeavor with the vibrantly devotional attitude. His thesis is, that the offering to man of a realizable Christian sanctity stands at the very center of the message of the Gospel. Bishop Peck makes the Scriptures the springboard of his writing; to this he beings a keen insight into the human moral predicament and a clear perspective upon the historical Wesleyan message. His work is clear, persuasive, and comprehensive. Few writers have presented the claim for the doctrine of Evangelical Perfection with better combination of "grace and truth."

The Christian View of God and World, by James Orr. New York: Scribners, 1904. (Eerdmans, \$5.00.)

The Kerr Lectures of Professor James Orr of the University of Glasgow have earned their place among the standard works in the field of religious philosophy. The sub-title indicates that the author found in the Incarnation the key to the comprehension of the Weltanschauung which the Christian system presupposes and/or engenders. Professor Orr develops two major themes: first, that the supernatural is an ineradicable element in the Christian system; and second, that the Incarnation of God in Christ is decisive for the Christian's appraisal of human nature, of the human moral predicament, and of human destiny. In the background of his thinking is always the factor of the Divine purpose back of the universe--this purpose being in a clear, if sometimes limited, fashion made known by a reverent study of the range of phenomenal factors with which life confronts us. Some find the work too concessive at a few points, notably its gradualism with respect to human origins. But the solid merits of the volume outweigh any such elements.

The Philosophy of Christianity, by Leander S. Keyser. Burlington, Iowa: The Lutheran Biterafry Board. 1928. (Muhlenberg Press, \$2.50.)

The late Professor Keyser of Hamma Divinity School has put the Christian world in his continuing debt through the pre-

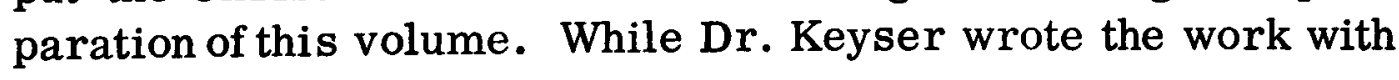


the view of producing a text book, he actually succeeded in giving to the general reader an appealing, instructive compendium. The author surveys a wide range of subjects which bear upon the Christian Faith, and develops the thesis that the Christian world-view is inclusive of the truth to be found in other systems, while at the same time correcting their errors and their inadequacies. Though written over thirty years ago, its insights are contemporary at many points. It "belongs" in the group of standard works for the minister's library.

Studies in Christian Philosophy, by W. R. Matthews. London: Macmillan and Co. , 1928.

Professor Matthews, retired dean of King's College in London, presented in his Boyle Lectures for 1920 a searching analysis of the question, Is there a characteristically Christian worldview? While the question is similar to that with which James Orr treated in his Kerr Lectures, Professor Matthews had the advantage of building upon a great deal of work done by contemporaries between 1895 and 1920. The author is keenly aware of the impact of Naturalism upon religious thought in our century. At times, he seems to make undue concessions to the naturalistic viewpoint. But if his work be read with this in mind, it offers a great deal which clarifies issues basic to religious philosophy.

Types of Religious Philosophy, by Edwin A. Burtt. New York: Harper's, 1951. $\$ 5.00$.

This work, a revision of the original volume of 1939 by the same title, attempts to survey the forms which the philosophy of religion has historically taken. Professor Burtt writes from the personal perspective of the religious humanist; this orientation colors his analyses of the several "types" which he analyzes. His treatment of "Protestant Fundamentalism" is geared largely to the stating of the similarities and differences between it and Roman Catholicism. The treatment of the Dialectical Theology (popularly, Neo-orthodoxy) is as sympathetic as might be expected from one whose view of human nature stems from his humanist orientation. The volume is, when read with the predilections of the author in mind ophelpful, to the comprehension 
of our religious scene. The comparative summaries at the end of each chapter are concise and clear.

\section{Apologetics}

Chance and Providence, by William G. Pollard. New York: Charles Scribner's Sons, 1958. \$4.50.

It is a rare combination, that a research scientist high in the counsels of Oak Ridge, should also be an ordained clergyman. Dr. Pollard seeks to present in this volume what he believes to be compelling evidence for a belief in an openness in the supposed regularities of our world which makes the theistic interpretation of the universe to be a valid option. This work expresses his mature judgment, made after years of study, and while it does not seek to present a final expertise, it does contain a stimulating approach to the question of the tenability of belief in the supernatural in a world like ours.

Christian Commitment. An Apologetic, by Edward John Carnell. New York: The Macmillan Company, 1957. \$5.00.

The development of Apologetics as an art rather than a science has led Dr. Carnell of Fuller Theological Seminary to elaborate a defense of the Christian Faith upon the basis of what he calls "The third method of knowing." This "third method" is a method conditioned by the voluntary acceptance of spiritual conviction, of moral commitment. Professor Carnell develops the view that the self-acceptance of moral responsibility can hold the key to a progressive career of knowing, ending with the personal knowledge of Jesus Christ, which knowledge is the crown-piece of the world-view known as Christian.

Reasons for Faith, by John 11.Gerstner. New York: Harper \& Brothers, 1960. $\$ 4.00$.

This highly capable author, orofessor of Church History and Government in Pittsburgh Theological Seminary, explores the prevalence and indispensability of faith forshife in general. But 
faith presupposes thought: and thought, when pursued in depth, leads one to see that the world is intelligible, and as such, leads one to a belief in a great deal else. This work explores in a careful fashion the alternatives to the Christian world-view, and seeks to establish that the Christian Faith "stands up" as a live option (to say the least) for the thinking man and woman.

Types of Apologetic Systems, by Bernard Ramm. Wheaton, Illinois: Van Kampen Press, 1953. \$3.00.

He who feels that the discipline of Apologetics is dead in our day should at least give consideration to this work by the professor of Systematic Theology at California Baptist Seminary. This work may be regarded as an attempt to re-awaken interest in traditional apologetics through an historical survey of a significant range of Christian apologists, past and present. It is especially to be recommended for its analyses of the apologetic methods of Joseph Butler and F. R. Tennant.

Varieties of Christian Apologetics, by Bernard Ramm. Grand Rapids, Michigan: Baker Book House, 1961. \$3.95.

This volume is a revision of Dr. Ramm's earlier work, Types of Apologetic Systems. It was rewritten with a view to adapting it to use as a text book. The range of materials covered is substantially the same as that of the earlier volume, but some articles are shortened, and the introduction has been altered so as to afford a better orientation to the subject. Both are well worth owning: if one can purchase but one, the revision is to be preferred.

\section{Psychology of Religion}

Philosophy of Christian Exoerience, by Randolph S. Foster. New York: Hunt \& Eaton, and Cineinnati: Cranston \& Stowe, 1890.

Among the time-tested works in this field, few are more instructive to those 
Bishop R. S. Foster which embodies the Merrick Foundation Lectures delivered at Ohio Wesleyan University. Bishop Foster writes as a committed Wesleyan and brings to his reader a penetrating analysis of the factors involved in evangelical religious experience, together with a discerning statement of the "possibilities of grace" and of the factors involved in the life of Christian sanctity.

Readings in the Psychology of Religion, edited by Orlo Strunk, Jr. New York and Nashville: Abingdon Press, 1959. \$4.50.

Those whose book budgets have prevented the purchase of many of the older standard works in the field of religious psychology (and especially those with a "liberal" orientation) will find that Professor Strunk, dean of West Virginia Wesleyan College, has in this volume presented the core of many of these works. In a chapter originally written for The Journal of Bible and Religion, the editor gives his own survey of the present status of his subject. The selection of chapters includes a number of more modern writers who seek to present contemporary views concerning the dynamics of human behavior as the question bears upon the psychology of religion.

Varieties of Christian Experience, by C. Sverre Norborg. Minneapolis: Augsburg Publishing House, 1937.

From the pen of a Lutheran minister has come an able analysis of William James' Gifford Lectures (Varieties of Religious Experience), and a statement of what seems to the author the vital core of Christian conversion. While appreciative of the constructive features of James' work, our author points out the underlying misconceptions which guide James' conclusions. This work makes no attempt to analyze those phases of Christian experience which follow conversion. The range of the author's scholarship and of his acquaintance with the general literature in the field of religious psychology is impressive. In a letter to this reviewer, Dry Norborg indicates that he is preparing a more comprehensive work in the same field. 


\section{Christian Ethics}

Christian Personal Ethics, by Carl F. H. Henry. Grand Rapids: Eerdmans, 1957. \$4.25.

It is only the occasional work in Christian Ethics which combines with effectiveness a survey of sub-Christian ethical systems and a systematic statement of the position of historic Christianity. Dr. Henry, editor of Christianity Today, has rendered us a distinct and effective service at this point. This volume includes an incisive statement of the major principles of the several forms of Naturalism as applied to "the Good Life," and less extensive but equally capable surveys of Idealistic and Existential ethical systems.

Our author's treatment of Section II of the work, "Christianity and the Moral Revelation," is carefully drawn, having the e special merit of treating the subject in the clear light of a "realistic" view of man's predicament as sinful, and in consequence a member of a "World of Fallen Morality." To this reviewer, Dr. Henry's treatment of the question of C onscience has no equal for thoroughness or for its correspondence to the biblical ideal. While the volume is eminently suitable for a textbook, it is likewise of abiding value to the minister in his week-by-week preparation.

An Introduction to Christian Ethics, by Warner Monroe. Anderson, Indiana: The Warner Press, 1947. \$2.95.

All writers upon the subject of Christian Ethics agree that the Christian principle of love, i.e., all-compelling love for God, and a love for the neighbor which is as profound as the love for the self, must be the point of departure. They differ widely at the point of the means by which the principle is brought to bear upon the concrete situation, and upon the specifics of human behavior. This volume seeks to effect a working synthesis of theory and practice in terms of man's basic capacities, especially his capacities for perceiving moral distinctions, for freedom, and above all, for seeking and securing divine assistance in the organization of the Christian 
life. It is intensely practical, richly suggestive, and scripturally sound.

The Principles of Christian Ethics, by Albert C. Knudson. New York: Abingdon, 1943. \$4.00.

Man's moral situation has been variously assessed in our generation, this being made necessary by two factors: first, the bland attitude toward personal sin which marked the "liberalmodernist" movement; and second, the vigorous reassertion of the "radical badness" of man by the Dialectical Theology. The late Professor Knudson never lets this problem slip far from his sight as he writes his volume, in which he seeks to defend the view that while there is something wrong with man, it is not "as wrong" as historic Christian thought has supposed.

Our author's analyses of the specific factors with which Christian Ethics is concerned are drawn with this in mind. His own position, in spite of some protestations to the contrary, approaches the Pelagian, especially in his treatment of the question of the need for conversion. His treatment of individual virtues is better than his discussion of the broad framework of ethics, and the entire work is limited by his optimistic assessment of the situation of the "natural" man.

\section{Contemporary Thought}

The Challenge of Existentialism, by John D. Wild. Bloomington, Indiana: University Press, 1955. \$6.00.

The factors leading to the fragmentation of philosophy in our world find an able survey in this work of Dr. Wild, of the University of Chicago. The author seeks to discover the roots of modern Existentialism in the thought of the past three centuries, and to discover what the positive contribution of the movement (in its serious form) may be for thought today. Written from the general vantage-point of modern classical realism, Professor Wild gives his reader o pentetrating analysis of the works of such writers as Kierkegaard, Jaspers, and Heidegger; he is an especially able exponent of the thought of the latter. This is not an easy volume to reads but the insights which it bears are highly rewarding to the one who would evaluate in a penetrating fashion the Existentialistemowement:HT PERMISSION 
Christianity and the Existentialists, ed. by Carl Michalson. New York: Scribner's, 1956. \$3.75.

The problematic quality of modern life has made itself felt in the field of the philosophy of religion these days in an especially conspicuous form in the movement known as Existentialism. Many discuss the movement without any precise understanding of what it is, or of what parentage it comes. This volume, comprising essays by eight authors, surveys the "existential" f a ctors in the writings of Kierkegaard, Unamuno, Berdyaev, Marcel, Heidegger, Holderlin and Rilke, as well as in some major forms of modern art. The editor defines his subject in the opening chapter, and seeks to separate the serious study of Existentialis m from the bizarre, the ill-defined, and the emotional elements which tend to gather about the term. The work is analytical, and does not seek to arrive at a conclusion. Its value lies in the range of the materials which it surveys.

Contemporary Evangelical Thought, ed. by Carl F. H. Henry. Great Neck, N. Y: Channel Press, 1957. \$5.00.

Anthologies are farfrom easy to control and unify; Dr. Henry, editor of the periodical, Christianity Today, has assembled chapters from ten writers whose common denominator is their c o m mitment to the principles of historic Christianity. The articles are concise and compactly written, and in general indicate a broad coverage of the several areas treated, which a re: Old Testament, New Testament, Systematic Theology, Ethics, Apologetics, Philosophy of History, Philosophy of Religion, Science and Religion, and Evangelism and Preaching. The several writers indicate an awareness of views divergent from their own, and in general, express their own positions well. The work contains a helpful bibliography.

Contemporary Religious Thought. An Anthology, ed. by Thomas S. Kepler. New Korkg Abingdon-Cokesbury Press, 1941. \$5.00.

Professor Kepler of Lawrence College presents in this volume a series of brief studies from a wide range of writers. The general topicsitreatedare thosercommon to the study of the 
general religious view of the world, i. e., The Nature of Religion, The Idea of God, The Problem of Evil, and Immortality among others. The authors are selected primarily from the orientations of the Liberal-Modernist and the Neo-supernaturalistic movements, with the former group predominating. The quality of the articles is not uniform; read discriminatingly, the book affords perspective upon the multiform nature of our theological scene of two decades ago, and had come contemporary relevance. 